\title{
Urinary retention: implications of low-fidelity simulation training on the self-confidence of nurses
}

\author{
Retenção urinária: implicações do treino simulado de baixa \\ fidelidade na autoconfiança do enfermeiro \\ Retención urinaria: implicaciones del entrenamiento simulado \\ de baja fidelidad en la autoconfianza del enfermero
}

Mateus Henrique Gonçalves Meska ${ }^{1}$ Alessandra Mazzo ${ }^{1}$, Beatriz Maria Jorge ${ }^{1}$, Valtuir Duarte de Souza-Junior ${ }^{1}$ Elaine Cristina Negri' ${ }^{1}$, Emília Maria Paulina Campos Chayamiti ${ }^{2}$

How to cite this article:

Meska MHG, Mazzo A, Jorge BM, Souza-Junior VD, Negri EC, Chayamiti EMPC. Urinary retention: implications of low-fidelity simulation training on the self-confidence of nurses. Rev Esc Enferm USP. 2016;50(5):831-837. DOI: http://dx.doi.org/10.1590/S0080-623420160000600017

${ }^{1}$ Universidade de São Paulo, Escola de Enfermagem de Ribeirão Preto, Centro Colaborador da OMS para o Desenvolvimento da Pesquisa em Enfermagem, Ribeirão Preto, SP, Brazil.

${ }^{2}$ Secretaria Municipal da Saúde de Ribeirão Preto, Coordenadoria do Serviço de Atenção Domiciliar, Ribeirão Preto, SP, Brazil.

\begin{abstract}
Objective: To evaluate the confidence level of nurses in nursing care in urinary retention before and after low-fidelity simulation training. Method: This was a quasi-experimental study carried out among nurses stationed in municipal care units in the interior of São Paulo State. Data were collected during the course of a pedagogical workshop that used low-fidelity simulation training. Results: The study included 42 nurses, mostly female with over 15 years of experience. After low-fidelity simulation training, nurses showed a significant increase $(p<0.05)$ in confidence related to nursing care in urinary retention. The lowest self-attributed scores during the activity were related to the objective assessment of urinary retention. Conclusion: Low-fidelity simulated training is an effective resource for the development of nurses with respect to nursing care in urinary retention.
\end{abstract}

DESCRIPTORS

Simulation; Teaching; Education, Nursing; Urinary Retention; Urinary Catheterization. 


\section{INTRODUCTION}

Urinary Retention (UR) can be defined as the partial or total spontaneous inability of the bladder to empty the urine produced by the kidneys. When acute, the individual feels that the bladder is distended, tense, and painful, and the ability to urinate is unsatisfactory. In chronic UR there is gradual bladder dilation; there may be an absence of pain, and dripping caused by leakage of urine from the bladder may also occur ${ }^{(1)}$.

In nursing care of patients with UR, the survey of the patient's clinical data to reach the correct diagnosis is the nurse's responsibility ${ }^{(2)}$, and so is adopting appropriate nursing interventions for UR. It is up to the professional to identify UR, describe its defining characteristics and related factors, and develop actions ranging from acute care to promoting patients' health. Among the most common treatment-related nursing interventions in UR is urinary catheterization ${ }^{(3)}$.

Within the nursing staff, urinary catheterization is an exclusive procedure of the nurse (Resolution No. 450/2013) $)^{(4)}$, which requires practice and scientific knowledge to be performed. It can be described as the drainage of urine through a catheter introduced into the urethra, which reaches the bladder interior. According to the length of stay in the urethra and the interval between procedures, urinary catheterization can be termed as delay, relieving, or intermittent. Urinary Tract Infection (UTI) has been reported among the main complications of the procedure. UTI is caused mainly by the catheter's length of stay in the urethra in delay catheterization and/or by the trauma caused by the improper introduction of the catheter. Urinary catheterization is frequently performed in a sterile manner within healthcare institutions, and in cases when the catheter will remain in the patient for a longer period of time (urinary delay catheters), and/or with the clean technique at home when the patient and/ or caregiver performs the procedure as a treatment ${ }^{(5-6)}$.

Urinary catheterization is an invasive procedure which, although much discussed in the literature, still presents the patient with physical and psychological complications, often caused by the nurse's unpreparedness and the lack of incorporation of scientific evidence into professional practice ${ }^{(5,7-8)}$. To be performed properly, the procedure relies on the participation of a nurse who is competent in technical development and decision-making, both in full patient care and in the procedure, choice of clean or sterile technique, and choice of materials to be used, among others. The decision concerning the catheter's length of stay in the urethra is up to the healthcare team; however, surveillance actions that minimize the possibility of patient exposure to a UTI should be part of the nurses' activities ${ }^{(5-6)}$.

Actions that bring professional improvement on the issue are extremely important to qualify the nursing work. To that end, in order to reduce procedure risk, and increase $\mathrm{pa}^{-}$ tient safety and professional confidence, the use of simulation training has been considered an appropriate alternative. Training using simulators improves, qualifies, and renews professional qualification ${ }^{(9-10)}$.
In nursing, the main purpose of simulation is to recreate and deliver experiences similar to the daily work in order to improve or expand knowledge and skills $s^{(11)}$. It provides professionals with experiences that enable or perfect nursing care perceptions, leading to the development of specific techniques in teamwork, critical-reflexive sense, and decision-making, which leads to more advantageous learning and safer practice both for the patient and the professional ${ }^{(12)}$.

Various types of simulators can be used to perform simulation activities, ranging from high performance clinical manikins to static models similar to human anatomy, also called simulators of low, medium, and high fidelity. Low-fidelity simulators have historically been used for urinary catheterization training. The low-fidelity simulator is a model aimed at replicating a particular anatomical body part partially or completely. It allows the performance of limited joint movements and does not present any response to external stimuli. These simulators are available, accessible, of low cost, and simple to maintain. They lead to skill development because they are suitable for teaching and demonstrating skills in various interventions ${ }^{(11)}$.

The use of simulators and simulation teaching has been considered an excellent resource for the development of selfconfidence among professionals ${ }^{(13)}$. The development of selfconfidence can be used as a precursor factor of better nursing care quality. Self-confidence can be characterized as the ability of the professional, in a given context, to manifest belief in self-success, self-power, and skills, leading to stability, autonomy, and positive results. To be achieved, it should be pursued with wisdom, support, and training, and cultivated with persistence, self-awareness, and positive thinking. It is related to self-efficacy and successful results. It can influence actions, behaviors, thinking patterns, and emotional reactions, leading to a belief in one's own abilities ${ }^{(14)}$.

Self-confidence is essential and influences nurses' behavior and professional lives, qualifying the patient's physical and psychological care ${ }^{(15)}$. In UR nursing care, and particularly in performing urinary catheterization, it generates a level of certainty for patients and health staff, positively impacting the procedure ${ }^{(8)}$. In this context, to qualify nursing care in UR and urinary catheterization, it is essential to format programs that build self-confidence through professional development and the development of clinical skills. Among the various strategies used for this purpose, simulation with low-fidelity simulators has been considered appropriate because of the nature of the intervention ${ }^{(16-17)}$.

This study aims to assess the self-confidence level of nurses in urinary retention nursing care before and after low-fidelity simulation training.

\section{METHOD}

This was a quasi-experimental study of a pre - and post-test group ${ }^{(18)}$, developed with nurses stationed in the Municipal Health Department of a health care unit in the state of São Paulo.

The study population was composed of nurses working in Primary and Secondary Healthcare Units, over 18 years old, who were guests and participants in a Urinary 
Incontinence educational workshop offered in partnership with the Municipal Health Department by formal invitation. Nurses who participated in the workshop and did not agree to participate in the study were excluded.

For the development of the activity, all nurses from primary and secondary healthcare units in the city were invited to attend an educational workshop on Incontinence offered by the researchers. Among the 63 participants, 42 joined this study.

It was a workshop consisting of two hours of theoretical activities and two hours of urinary catheterization low-fidelity simulation practice, followed by reflection. In simulation practices carried out in groups of 10 , the nurses performed urinary catheterizations of relief and/or intermittent, male and female, and urinary catheterizations of delay. Different materials and technologies were also manipulated. The practice simulators consisted of anatomical parts and/or whole body manikins (Laerdal $\left.{ }^{\oplus}\right)$, which enable the introduction of the urinary catheter and urine drainage (liquid introduced into the simulator compartment that reproduces the human bladder).

To identify the confidence of nurses before and after the workshop, the subjects were asked to fill in a population characterization instrument and Self-Confidence Scale in Nursing Care in Urinary Retention (SSNCUR) ${ }^{(8)}$.

SSNCUR was built and validated for use in the Portuguese language ${ }^{(8)}$. Its goal is to evaluate the nurse's self-confidence in UR Nursing Care. It is a scale of 32 items with Likert-like responses of five points: "not confident", "little confident", "confident", "very confident," and "completely confident," grouped into five factors: 1)
"Interventions performed during urinary catheterization and/or iatrogenic situations"; 2) "Interventions prior to urinary catheterization"; 3) "Interventions after urinary catheterization"; 4) "Communication, consent, and preparation of materials for performing urinary catheterization"; and 5) "UR objective evaluation".

The survey data were coded and double-entered in an Excel application spreadsheet, and exported and analyzed in the software SAS/STAT ${ }^{\circledast}$ (Statistical Analysis System), 9.0. Responses to SSNCUR items were scored from 1 to 5. Internal consistency calculations and scale factors analysis were performed, as recommended in the original instrument ${ }^{(8)}$. Data were analyzed using the SPSS software (version 22 for Windows). For all statistical tests the value of $\mathrm{p}<0.05$ was assumed as a critical significance level.

This study was approved by the Research Ethics Committee of the Escola de Enfermagem de Ribeirão Preto, with the approval of the Ribeirão Preto Municipal Health Department (No.505722/2013), according to CNS Resolution 466/2012. Nurses formalized the acceptance by signing the Informed Consent Form.

\section{RESULTS}

Among the 42 subjects who participated in the study, one (2.4\%) was a man and 41 (97.6\%) were women. Regarding graduation, 29 (69.0\%) had a specialization, five (11.9\%) a master's degree, and only one (2.4\%) a Ph.D. Subjects' ages, years since graduation, and lengths of professional experience are described in Table 1.

Table 1 - Subjects' ages and lengths of professional experience - Ribeirão Preto, São Paulo, Brazil, 2014.

\begin{tabular}{|c|c|c|c|c|c|}
\hline Age & $F(\%)$ & Year of graduation & $F(\%)$ & Length of professional experience & $F(\%)$ \\
\hline 26 to 30 & $5(11.9 \%)$ & 1974 to 1980 & $5(11.9 \%)$ & Up to 5 years & $3(7.4 \%)$ \\
\hline 31 to 40 & $14(33.3 \%)$ & 1981 to 1990 & $18(42.8 \%)$ & 6 to 10 years & $9(21.4 \%)$ \\
\hline 41 to 50 & $7(16.7 \%)$ & 1991 to 2000 & $4(9.5 \%)$ & 11 to 15 years & $3(7.4 \%)$ \\
\hline 51 to 63 & $16(38.1 \%)$ & 2001 to 2010 & $9(21.4 \%)$ & 16 to 20 years & $2(4.7 \%)$ \\
\hline- & - & 2011 to 2014 & $6(16.3 \%)$ & 21 to 25 years & $6(14.3 \%)$ \\
\hline- & - & - & - & 26 to 30 years & $12(28.5 \%)$ \\
\hline- & - & - & - & 31 to 35 years & $5(11.9 \%)$ \\
\hline- & - & - & - & 36 to 40 years & $2(4.7 \%)$ \\
\hline
\end{tabular}

Before training on low-fidelity manikins, subjects were questioned about having already performed the UR patient's evaluation, and among them $36(85.7 \%)$ replied yes and six (14.3\%) said no. Regarding the degree of difficulty to carry out the UR patient's evaluation, three (7.1\%) reported it as very low, 26 (61.9\%) as low, and 13 (31.0\%) as high. As for the urinary catheterization technique, 40 (95.2\%) reported having already performed it, and two reported (4.8\%) not having done so. Regarding the degree of difficulty in performing the catheterization, $11(26.2 \%)$ considered it very low, 22 (52.5\%) low, and nine (21.4\%) considered it high.

Regarding the degree of difficulty in assessing UR patients after training on the low-fidelity simulator, four
(9.5\%) reported it as very low, 25 (59.5\%) as low, $12(28.6 \%)$ as high, and one (2.4\%) as very high. The degree of difficulty in performing the technique of urinary catheterization after simulator training was ranked by nine $(21.4 \%)$ as very low, by $22(52.4 \%)$ as low, by nine $(21.4 \%)$ as high, and by two $(4.8 \%)$ as very high.

Table 2 shows the self-concepts applied by these professionals regarding proficiency, skill, knowledge, and interaction with patients during UR evaluation and urinary catheterization performance.

Regarding the use of SSNCUR, as in the original instrument, high Alpha Cronbach values were obtained for all dimensions of the scale (0.965) for the sample studied, demonstrating the instrument reliability. 
Table 2 - Self-concept assigned by professionals in UR evaluation and urinary catheterization - Ribeirão Preto, São Paulo, Brazil, 2014.

\begin{tabular}{|c|c|c|c|c|}
\hline & \multicolumn{4}{|c|}{ Before simulation training } \\
\hline & Mean & Standard deviation & Minimum & Maximum \\
\hline \multicolumn{5}{|l|}{$U R$} \\
\hline Proficiency & 6.3 & 1.7 & 1.0 & 10.0 \\
\hline Skill & 6.5 & 1.5 & 1.0 & 10.0 \\
\hline Knowledge & 7.6 & 1.6 & 1.0 & 10.0 \\
\hline Interaction & 7.6 & 1.6 & 2.0 & 10.0 \\
\hline \multicolumn{5}{|c|}{ Urinary catheterization } \\
\hline Proficiency & 7.9 & 1.5 & 1.0 & 10.0 \\
\hline Skill & 7.8 & 1.3 & 1.0 & 10.0 \\
\hline Knowledge & 8.1 & 1.4 & 4.0 & 10.0 \\
\hline Interaction & 8.3 & 1.2 & 5.0 & 10.0 \\
\hline \multicolumn{5}{|c|}{ After simulation training } \\
\hline \multicolumn{5}{|l|}{$U R$} \\
\hline Proficiency & 7.8 & 1.3 & 1.0 & 10.0 \\
\hline Skill & 7.9 & 1.3 & 1.0 & 10.0 \\
\hline Knowledge & 8.1 & 1.4 & 4.0 & 10.0 \\
\hline Interaction & 8.6 & 1.2 & 4.0 & 10.0 \\
\hline \multicolumn{5}{|c|}{ Urinary catheterization } \\
\hline Proficiency & 8.4 & 1.5 & 1.0 & 10.0 \\
\hline Skill & 8.6 & 1.0 & 1.0 & 10.0 \\
\hline Knowledge & 8.8 & 1.0 & 6.0 & 10.0 \\
\hline Interaction & 9.0 & 0.9 & 7.0 & 10.0 \\
\hline
\end{tabular}

With regard to self-confidence in UR nursing care, through SSNCUR scores from 2.1 to 5.0 were assigned by nurses at the time of data collection, before low-fidelity simulation training, and from 2.3 to 5.0 after low-fidelity simulation training. The scores self-attributed by nurses are shown in Table 3 .

Table 3 - Values assigned to self-confidence in UR Nursing Care, before and after low-fidelity simulation training - Ribeirão Preto, São Paulo, Brazil, 2014.

\begin{tabular}{|c|c|c|c|c|c|c|c|c|}
\hline \multirow{3}{*}{$\begin{array}{l}\text { Self- } \\
\text { confidence }\end{array}$} & \multicolumn{8}{|c|}{ Simulation training } \\
\hline & \multicolumn{2}{|c|}{ Mean } & \multicolumn{2}{|c|}{$\begin{array}{l}\text { Standard } \\
\text { deviation }\end{array}$} & \multicolumn{2}{|c|}{ Minimum } & \multicolumn{2}{|c|}{ Maximum } \\
\hline & Before & After & Before & After & Before & After & Before & After \\
\hline Factor 1 & 3.5 & 4.2 & 0.7 & 0.7 & 2.1 & 2.4 & 4.9 & 5.0 \\
\hline Factor 2 & 4.3 & 4.6 & 0.6 & 0.6 & 3.0 & 3.0 & 5.0 & 5.0 \\
\hline Factor 3 & 3.8 & 4.4 & 0.6 & 0.7 & 2.3 & 2.7 & 5.0 & 5.0 \\
\hline Factor 4 & 4.0 & 4.0 & 0.6 & 0.6 & 2.3 & 3.0 & 5.0 & 5.0 \\
\hline Factor 5 & 3.1 & 3.6 & 0.6 & 0.7 & 2.3 & 2.3 & 4.8 & 5.0 \\
\hline General & 3.8 & 4.2 & 0.5 & 0.6 & 2.5 & 2.8 & 4.8 & 5.0 \\
\hline
\end{tabular}

The analysis obtained by the Kolmogorov-Smirnov test showed the sample had a normal distribution ( $p>0.05)$, so the T-test was used to compare the self-confidence measured before and after low-fidelity simulation, assuming a confidence interval of $95.0 \%$. As seen in Table 4, results showed a significant increase in self-confidence after lowfidelity simulation training in both the overall score and in all of the factors composing the scale.
Table 4 - Significance level of the comparison between values self-attributed for self-confidence in UR Nursing Care, before and after low-fidelity simulation - Ribeirão Preto, São Paulo, Brazil, 2014.

\begin{tabular}{|c|c|c|c|c|}
\hline \multirow{2}{*}{$\begin{array}{l}\text { Self- } \\
\text { confidence }\end{array}$} & \multicolumn{2}{|c|}{ Mean } & \multirow{2}{*}{$\mathbf{t}$} & \multirow{2}{*}{$p$-value } \\
\hline & Before & After & & \\
\hline Factor 1 & 3.5 & 4.2 & -7.158 & $<0.001$ \\
\hline Factor 2 & 4.3 & 4.6 & -2.762 & 0.009 \\
\hline Factor 3 & 3.8 & 4.4 & -5.575 & $<0.001$ \\
\hline Factor 4 & 4.0 & 4.0 & -4.261 & $<0.001$ \\
\hline Factor 5 & 3.1 & 3.6 & -6.030 & $<0.001$ \\
\hline General & 3.8 & 4.3 & -6.195 & $<0.001$ \\
\hline
\end{tabular}

\section{DISCUSSION}

Humans are active beings in the construction of knowledge, and constantly seek ways to develop and improve their skills. Education is a human activity necessary to the existence and functioning of the whole society, and the process of knowledge acquisition and experience gathering is one that empowers and transforms reality ${ }^{(19)}$.

Continuing education of health professionals should be part of professionals' thoughts and actions. It is intended to provide individual personal and professional growth, contribute to the organization of work processes, and aim for quality health care for the effective articulation of improvement actions and of management and care processes ${ }^{(20)}$. 
Deficiencies in training and in the promotion of continuing education are constant threats that have compromised the safety and practice of professions, among which nursing stands out in the healthcare area ${ }^{(21)}$. For nursing practice development and projection, it is necessary for nurses to permanently commit to learning, so that they can teach and direct their team's work. More training protects the profession and promotes quality and safety for health preservation, restoration, and promotion.

To minimize the difficulties arising from this issue, it is essential to format educational projects in institutions. Education linked to the labor market favors learning, promotes a more critical and reflexive view of actions, and ensures quality patient care ${ }^{(22)}$.

Urinary catheterization stands out among the many situations that put patients and professionals at risk, because of its high frequency in clinical practice. In this study's sample most of the interviewed nurses had long training and experience in the profession, as shown in Table 1 and Table 2; however, some had never performed an evaluation of UR and/or urinary catheterization, and attributed a low complexity level to these procedures.

The risk involving the patient submitted to urinary catheterization recently led the Federal Council of Nursing ${ }^{(4)}$ to recommend that the urinary catheter insertion is an exclusive function of nurses. The Council stated that the urinary catheterization procedure should be performed with the technical-scientific rigor necessary given its complexity, and points to the importance of the nursing staff's continuing education for the incorporation of best practices, with the support of the academic and clinical areas, supported by the best and most recent evidence ${ }^{(4)}$. Recent studies have, however, evidenced the use of ritualistic practices in this issue, sustained by low evidence that affects both the procedures performed by professionals within institutions, and the clean intermittent urinary catheterization performed by patients and/or families at home ${ }^{(5,8,23)}$.

Using the best evidence in clinical practice qualifies and ensures nursing care. It also involves constant professional updating, and requires teaching-learning strategies that encourage participation and improvement. Among the various activities proposed, because it is an active and meaningful teaching-learning method, simulation has been considered an admirable strategy. Simulation brings students closer to practice and does not treat them as passive recipients. It can be characterized by cognitive interaction between students' new and prior knowledge. In simulated activities it is possible to build, rebuild, learn, and relearn meaningfully, which can be widely used in practice ${ }^{(11,24)}$.

The use of simulated teaching has been related to gaining knowledge, satisfaction with education, and students' selfconfidence. In this sample, the use of low-fidelity simulation raised the perception of some subjects about the degree of difficulty in performing urinary catheterization and UR evaluation, increasing the self-attributed scores for proficiency, skill, knowledge, and interaction in both areas after training. In addition, as shown in Table 3, the overall mean attributed for SelfConfidence in Urinary Retention Nursing Care increased.
In this study about nursing care in Urinary Retention Evaluation before and after performing the low-fidelity simulation training, the lowest self-confidence means attributed by nurses were for urinary retention objective Evaluation (Factor 5), and the highest for previous Interventions performing urinary catheterization (Factor 2). It is important to note that Interventions prior to performing urinary catheterization involve hygiene and antisepsis, objective UR Evaluation, and bladder clinical examination ${ }^{(8)}$. While the first steps are likely to be carried out in low-fidelity simulators, performing objective UR Evaluation is limited with this type of equipment, which may have been a limiting factor in this study. The use of dramatization is indicated for training in objective UR evaluation (role play, simulated patient, or mixed simulator).

A recent study showed that objective UR evaluation is the item to which nurses have assigned the lowest selfconfidence level during UR nursing care ${ }^{(8)}$, and therefore requires greater investment by training centers. Physical bladder examination involves inspection, palpation, and organ percussion intended to identify texture changes, thickness, consistency, sensitivity, volume, and hardness. It involves the examiner's subjectivity, changes in the patient's operational and clinical conditions (e.g., changes due to drug use and age $)^{(17,25)}$. To be done safely and accurately, it involves the use of technology, exemplified by portable bladder ultrasound.

Portable bladder ultrasound is a device that has been available on the market since the 1980s; however, it is still rarely used in clinical patient care in Brazil, and is almost nonexistent in training centers. It overcomes the subjectivity of physical examination and leads to early UR diagnosis, indicating whether or not urinary catheterization should be performed, and therefore dramatically reducing UTI rates ${ }^{(17,25)}$.

Low-fidelity simulation can be considered a low-cost practice easily accessible to institutions, which makes it feasible for the improvement of nursing professionals. It has also proven to be effective in urinary catheterization manual dexterity training ${ }^{(11)}$. Although the use of low-fidelity simulators does not provide bladder physical examination, in this study's sample it proved to be effective in developing the selfconfidence of nurses in UR Nursing Care. As shown in Table 4 , there were significant changes in nurses' self-confidence $(p<0.05)$ for all of the factors evaluated by the collection instrument after low-fidelity simulation training. The factors were: 1) "Interventions performed during urinary catheterization and/or iatrogenic situations"; 2) "Interventions prior to urinary catheterization"; 3) "Interventions performed after urinary catheterization"; 4) "Communication, consent, and preparation of materials for performing urinary catheterization"; and 5) "UR objective evaluation."

Self-confidence underlies competence and success. It is part of an internal construct that affects performance and, in UR nursing care, directs interventions related to urinary catheterization properly. It results in better outcomes for patients and effective professional performance. Selfconfident nurses have the skills of critical analysis, reflection, problem-solving and, especially, decision-making ${ }^{(8,16,26-27)}$. 


\section{CONCLUSION}

Active teaching-learning methods such as the use of simulation have been an important strategy for professional development in the qualification for urinary retention nursing care.

Among the various possibilities of resource usage that simulation training offers, low-fidelity simulators have been highlighted as a resource within the reach of health institutions for their affordable cost and easy utilization, which gives them great potential in professional improvement.

Aimed at training in skills such as urinary catheterization, low-fidelity simulators demonstrated efficacy in the development of professional self-confidence in urinaryretention nursing care. However, when used in the patient's clinical evaluation, better analysis is required, due to resource interaction limitations.

\section{RESUMO}

Objetivo: Avaliar o nível de autoconfiança de enfermeiros na assistência de enfermagem na retenção urinária antes e após atividade simulada de baixa fidelidade. Método: Estudo quase-experimental realizado junto aos enfermeiros lotados nas unidades de atendimento de município do interior do estado de São Paulo. Os dados foram coletados durante a realização de uma oficina pedagógica que contou com atividade simulada de baixa fidelidade. Resultados: Participaram do estudo 42 enfermeiros, a maioria do sexo feminino e com mais de 15 anos de atuação. Após o treino simulado de baixa fidelidade os enfermeiros demonstraram aumento significativo $(p<0,05)$ na autoconfiança relacionada à assistência de enfermagem na retenção urinária. Os menores escores autoatribuídos durante a atividade foram relacionados à avaliação objetiva da retenção urinária. Conclusão: A simulação de baixa fidelidade é um recurso efetivo no aprimoramento de enfermeiros no que diz respeito à assistência de enfermagem na retenção urinária.

\section{DESCRITORES}

Simulação; Ensino; Educação em Enfermagem; Retenção Urinária; Cateterismo Urinário.

\section{RESUMEN}

Objetivo: Evaluar el nivel de autoconfianza de enfermeros en la asistencia de enfermería en la retención urinaria antes y después de actividad simulada de baja fidelidad. Método: Estudio cuasi-experimental realizado junto a los enfermeros ubicados en las unidades de atención de municipio del interior del Estado de São Paulo. Los datos fueron recolectados durante la realización de un taller pedagógico que contó con actividad simulada de baja fidelidad. Resultados: Participaron en el estudio 42 enfermeros, la mayoría del sexo femenino y con más de 15 años de actuación. Después del entrenamiento simulado de baja fidelidad, los enfermeros demostraron aumento significativo $(p<0,05)$ en la autoconfianza relacionada con la asistencia de enfermería en la retención urinaria. Los menores puntajes autoatribuidos durante la actividad estuvieron relacionados con la evaluación objetiva de la retención urinaria. Conclusión: La simulación de baja fidelidad es un recurso efectivo en el perfeccionamiento de enfermeros en lo que se refiere a la asistencia de enfermería en la retención urinaria.

\section{DESCRIPTORES}

Simulación; Enseñanza; Educación en Enfermería; Retención Urinaria; Cateterismo Urinario.

\section{REFERENCES}

1. Queiroz e Silva FA, Simões FA. Semiologia urológica. In: Nardozza Júnior A, Zerati Filho M, Reis RB. Urologia fundamental. São Paulo: Planmark; 2010. p. 37-46.

2. Cruz DALM, Guedes ES, Santos MA, Sousa RMC, Turrini RNT, Maia MM, et al. Nursing process documentation: rationale and methods of analytical study. Rev Bras Enferm. 2016;69(1):197-204.

3. Mazzo A, Godoy S, Alves LM, Mendes IAC, Trevizan MA, Rangel EML. Cateterismo urinário: facilidades e dificuldades relacionadas à sua padronização. Texto Contexto Enferm. 2011;20(2):333-9.

4. Conselho Federal de Enfermagem (COFEN). Resolução n. 450, de 11 de dezembro de 2013. Normatiza o procedimento de Sondagem Vesical no âmbito do Sistema Cofen/Conselhos Regionais de Enfermagem [Internet]. Brasília: COFEn; 2013 [citado 2015 jan. 29$].$ Disponível em: http://www.cofen.gov.br/resolucao-cofen-no-04502013-4_23266.html

5. Mazzo A, Gaspar AACS, Mendes IAC, Trevizan MA, Godoy S, Martins JCA. Urinary catheter: myths and rituals present in preparation of patients. Acta Paul Enferm. 2012;25(6):889-94.

6. Center for Disease Control and Prevention (CDC). Guideline for prevention of catheter - associated urinary tract infections [Internet]. Atlanta; 2009 [cited 2015 Jan 29]. Available from: http://www.cdc.gov/hicpac/cauti/001_cauti.html

7. Jorge BM, Mazzo A, Mendes IAC, Trevizan MA, Martins JCA. Infeção do trato urinário relacionada com o uso do cateter: revisão integrativa. Rev Enf Ref. 2013; serllI(11):125-32.

8. Mazzo A, Martins JCA, Jorge BM, Baptista RCN, Almeida RGS, Henriques FMD, et al. Validation of the self-confidence scale of nursing care in urinary retention. Rev Latino Am. Enfermagem. 2015;23(5):814-20.

9. Deutschmann MW, Yunker WK, Cho JJ, Andreassen M, Beveridge S, Bosch JD. Use of a Low-fidelity simulator to improve trans-nasal fibre-optic flexible laryngoscopy in the clinical setting: a randomized, single-blinded, prospective study. J Otolaryngol Head Neck Surg. 2013;42(1):35.

10. Tosteruda R, Hedelinb B, Hall-Lorda ML. Nursing students' perceptions of high - and low-fidelity simulation used as learning methods. Nurse Educ Pract. 2013;13(4):262-70. 
11. Martins JCA, Mazzo A, Baptista RCN, Coutinho VRD, Godoy S, Mendes IAC, et al. The simulated clinical experience in nursing education: a historical review. Acta Paul Enferm. 2012;25(4):619-25.

12. Levett-Jones T, Lapkin S. A systematic review of the effectiveness of simulation debriefing in health professional education. Nurse Educ Today. 2014;34(6):58-63.

13. Martins JCA, Baptista RCN, Coutinho VDC, Mazzo A, Rodrigues MA, Mendes IAC. Self-confidence for emergency intervention: adaptation and cultural validation of the Self-confidence Scale in nursing students. Rev Latino Am Enfermagem. 2014;22(4):554-61.

14. Van Dyk J, Siedlecki SL, Fitzpatrick JJ. Frontline nurse managers' confidence and self-efficacy. J Nurs Manag. 2016;24(4):533-9.

15. Valizadeh L, Zamanzadeh V, Gargari RB, Ghahramanian A, Tabrizi F J, Keogh B. Pressure and protective factors influencing nursing students' self-esteem: a content analysis study. Nurse Educ Today. 2016;36:468-72.

16. Franklin AE, Lee CS. Effectiveness of simulation for improvement in self-efficacy among novice nurses: a meta-analysis. J Nurs Educ. 2014;53(11):607-14.

17. Daurat A, Choquet O, Bringuier S, Charbit J, Egan M, Capdevila X. Diagnosis of postoperative urinary retention using a simplified ultrasound bladder measurement. Anesth Analg. 2015;120(5):1033-8.

18. Sousa VD, Driessnack M, Mendes IAC. An overview of research designs relevant to nursing: Part 1: quantitative research designs. Rev Latino Am Enfermagem. 2007;15(3):502-7.

19. Paschoal AS, Mantovani MF, Méier MJ. Percepção da educação permanente, continuada e em serviço para enfermeiros de um hospital de ensino. Rev Esc Enferm USP. 2007;41(3):478-84.

20. Sade PMC, Peres AM. Development of nursing management competencies: guidelines for continuous education services. Rev Esc Enferm USP. 2015;49(6):988-94.

21. Fassini P, Hahn GV. Riscos à segurança do paciente em unidade de internação hospitalar: concepções da equipe de enfermagem. Rev Enferm UFSM. 2012;2(2):290-9.

22. Miccasi FL, Batista SHSS. Educação permanente em saúde: metassíntese. Rev Saúde Pública. 2014;48(1):170-85.

23. Mazzo A, Souza-Junior VD, Jorge BM, Nassif A, Biaziolo CF, Cassini M, et al. Intermittent urethral catheterization-descriptive study at a Brazilian service. Appl Nurs Res. 2014;27(3):170-4.

24. Sousa ATO, Formiga NS, Oliveira SHS, Costa MML, Soares MJGO. Using the theory of meaningful learning in nursing education. Rev Bras Enferm. 2015;68(4):713-22.

25. Shimoni Z, Fruger E, Froom, P. Measurement of Post-void Residual Bladder Volumes in Hospitalized Older Adults. Am J Med. 2015;128(91):77-81.

26. Lubbers J, Rossman C. The effects of pediatric community simulation experience on the self-confidence and satisfaction of baccalaureate nursing students: a quasi-experimental study. Nurse Educ Today. 2016;39:93-8.

27. Cummings CL, Connelly LK. Can nursing students' confidence levels increase with repeated simulation activities? Nurse Educ Today. 2016;36:419-21.

Financial support: Fundação de Amparo à Pesquisa do Estado de São Paulo (FAPESP). Case no. 2012024533-5. Conselho Nacional de Pesquisa Científica (CNPq). Case no. 303129/2014-0. 